\title{
Simulation of water cycle components in the Narmada River basin by forcing SWAT model with CFSR data
}

\author{
Suresh B. Goswami, Sarat C. Kar \\ National Center for Medium Range Weather Forecasting, Ministry of Earth Sciences, A-50, Sector-62, NOIDA, \\ UP, Pin: 201 309, India
}

\begin{abstract}
In the present study, an attempt has been made through a hydrological model (SWAT - Soil and Water Assessment Tool) to simulate water cycle components over the Narmada river basin, one of the largest rivers in the Indian peninsula. The model was forced with observed as well as CFSR rainfall data to calibrate surface runoff simulated by the model. The spatial and temporal variability of the water cycle components were examined by running the SWAT model for 30 years (1984-2013) at a daily time-scale using CFSR precipitation, temperature, humidity, winds and solar radiation. It was found that there are large variations in hydrological parameters simulated by the model from sub-basin to sub-basin and year to year. During the monsoon seasons, surface runoff is maximum but during other seasons, almost no surface runoff is seen as there is almost no rain. Groundwater increase is seen after about 1 month of rainfall peaks in the basin. Evapotranspiration has two peaks, one in March-April and the other in August. Much less evaporation takes place in the basin in the month of May. These components (other than surface runoff) are also sensitive to climatic forcing (winds, relative humidity and solar radiation in addition to temperature and rainfall) applied. Evapotranspiration increases when all the climatic parameters are used, which then reduces the water availability on the surface for percolation and groundwater recharge. However, rainfall is the key parameter which decides the hydrology in the Narmada basin. The SWAT model has been able to compute water balance at basin and sub-basin scales.
\end{abstract}

Keywords: hydrology, water cycle, SWAT, CFSR data

Submitted 18 April 2017, revised 9 June 2017, accepted 3 August 2017

\section{Introduction}

The importance of study of water resources at river catchment scale to assess and manage water resources has been widely highlighted (e.g. Stehr et al. 2008). Many complex multiscale interactions and feedbacks take place in the water cycle over a given river basin. Complete information on the hydrological cycle (such as precipitation, evapotranspiration, potential Evapotranspiration, surface runoff and base flow) over a basin is not easy because observations of these components of water cycle are not available at the regional scale. To understand the key processes of water cycle through numerical model, better representation, evaluation and validation of all components of the simulated water cycle by a model are required. Changes in water cycle are particularly difficult to model because major uncertainties exist in the representation of processes such as large-scale and convective rainfall and their feedback with surface conditions. Inadequate understanding of the hydrological cycle and limited ability of the models to simulate the various hydrological processes and their associated feedbacks contribute to the uncertainties associated with quantification of long-term changes in the climate system (IPCC 2001). According to several authors such as Huntington (2006), there is robust evidence of current and future intensification of the hydrological cycle. There has been several climate modelling studies to understand the water cycle processes and to evaluate water cycle in global warming era (Allan, Liepert 2010). Past studies have identified several systematic and persistent biases in the representation of the global water cycle in climate models (Mehran et al. 2014). These biases reduce our confidence in the model to accurately predict how the water cycle will respond to changes in future forcings and feedbacks. Waliser et al. (2007) examined the global water cycle in the models used by Inter-Governmental Panel on Climate Change (IPCC) for its fourth assessment report (IPCC-AR4) and found that the models could simulate well only those quantities that had a robust global observational basis and that are physically unambiguous.

Calculating multi-model means of simulations and multi-model means of subsets of simulations is a common approach in recent years. While the basic processes are well known and the acceleration of the water cycle with global warming is well studied, the inter-model variability of variables describing hydrological processes remains high (Liepert, Previdi 2009). Regional climate models (RCMs) are powerful tools in quantitative studies of the 
hydrological cycle at the continental and subcontinental scales. These models can reproduce many of the complex processes in the hydrological cycle and can generate information about hydrological cycle components that are difficult to measure. Music and Caya (2009) used the Canadian Regional Climate Model (CRCM) model to examine the sensitivity of the land surface schemes for three North American watersheds - the Mississippi, the St. Lawrence, and the Mackenzie River basins. They found that the sensitivity of climatological means and annual cycles of water budget components to land surface parameterizations varied from basin to basin. It is clear that deficiencies in hydrological cycle modeling induce errors in regional climate simulations. These errors depend on the skill of the model itself, but also on the quality of the data used to drive the regional model at its boundaries. Kleinn et al. (2005) had evaluated a model chain for studying streamflow responses to climate variations and anthropogenic climate change for the Rhine basin upstream of Cologne in Central Europe, north of the Alps. Though the model chain was able to represent key processes related to streamflow variations in response to climate variations and climate change, they found that the horizontal resolution of the regional model did not have a significant impact on the skill of the hydrological model to simulate streamflow.

With the help of hydrological models one can make a detailed study of the hydrological cycle at river-basin scale (Bastidas et al. 2003). During last four decades, various open source simulation models have been developed for watershed analyses such as HSPF (Hydrological Simulation Program), HEC-HMS (Hydrologic Modeling System), CREAMS (Chemical, Runoff, and Erosion from Agricultural Management Systems), EPIC (Erosion-Productivity Impact Calculator), and AGNPS (Agricultural Non-Point Source). Each model has its own specification and limitation restricting their application. A widely used physically based SWAT (Soil and Water Assessment Tool) model has proven very successful in the watershed assessment of hydrology. It has the capability to compute hydrologic components such as surface runoff, base flow, evapotranspiration (ET), and soil moisture change for each HRU. Netnapa and Pongthep (2013) applied the SWAT model to evaluate the prediction capability for streamflow in Upper Lam Takong sub-watershed. In this study, the model was calibrated for 2007-2008 and validated for 2009. Calibration and validation results showed that the simulated monthly flows were in reasonable agreement with measured values. Manaswi and Thawati (2014) employed the SWAT model for runoff modelling of the Karam River basin, a tributary of the Narmada river basin for calibration of the model for 10 years (2000-2010).
The results prove that the simulated runoff is closer to the observed runoff.

Evapotranspiration (ET) is an important component of the water cycle - changes in it would affect the whole water cycle. Potential Evapotranspiration $(P E T)$ is defined as the amount of water that can be evaporated and transpired when soil water is sufficient to fulfil atmospheric demand (Allen et al. 1998). Wang et al. (2006) applied the SWAT model for cropland dominated watershed in north-western Minnesota to examine how various methods of PET modeling affected surface runoff predictions. However, Wang et al. (2006) found that in the SWAT model, the annual mean discharges with a higher value were generally predicted more accurately by the Priestley method, whereas the discharges with a lower value were usually predicted better by the Hargreaves method. Earls and Dixon (2008) concluded that the characterization of PET model was critical in hydrological budgets, rainfall runoff models, infiltration calculations, and drought prediction models since ET is a large component of the water balance in a humid environment.

The water cycle (transformation of rainfall into runoff, evapotranspiration and ground water etc.) of the Narmada river basin is a very complex process due to heterogeneities in topography, land cover and other catchment features. There have only been a few studies on only the runoff aspect of the hydrology of the Narmada River basin. The main reason for this is a lack of consistent and long-term data needed for such studies. The main objective of this study is to estimate the key components of the water cycle forcing the SWAT model with CFSR reanalysis data for 30 years (1984 to 2013). Section 2 of the paper describes the study region briefly. The model, datasets used and methodology are presented in Section 3. The main results are discussed in Section 4. The study is concluded in Section 5.

\section{Study area}

The present study has been conducted for the Narmada river basin, and the location of the basin is shown in Fig. 1a. It is the largest west-flowing and the fifth largest river in the Indian Peninsula. The Narmada basin represents a highly complex hydrological system. The river is fed by a large number of rivers and rivulets running down from both mountain ranges in central India. The river forms the traditional boundary between north India and south India. The river basin lies between $72^{\circ} 32^{\prime} \mathrm{E}$ to $81^{\circ} 45^{\prime} \mathrm{E}$ longitudes and between $21^{\circ} 20^{\prime} \mathrm{N}$ to $23^{\circ} 45^{\prime} \mathrm{N}$ latitudes. According to the Narmada Control Authority (NCA Website), the river drains an area of 
98,796 sq.kms out of which nearly $86 \%$ lies in Madhya Pradesh, $3 \%$ in Maharashtra and $11 \%$ in Gujarat. The tropic of Cancer crosses the Narmada River basin in the Upper plains area and most of the basin lies just south of this line. The climate of the basin is humid and tropical, although in places, extremes of heat and cold are often encountered.

\section{Model, data and experiments \\ 3.1. SWAT Model configuration}

For the present study, the SWAT model is used for the assessment of water cycle components such as surface runoff, percolation, groundwater flow, water yield, evapotranspiration $(E T)$ and potential evapotranspiration (PET) estimation. SWAT is an open source hydrologic model, which was developed by the USDA Agricultural Research Service. It is a long-term, continuous simulation watershed model. It operates on a daily time step and is designed to predict the impact of management on water, sediment, and agricultural chemical yields (Arnold et al. 1998). The hydrological cycle is based on the water balance equation, which is represented in equation:

$$
S W_{t}=S W_{0}+\sum_{t=1}^{\mathrm{t}}\left(R_{d a y}-Q_{\text {surf }}-E_{a}-W_{\text {seep }}-Q_{q w}\right)
$$

where: $S W_{t}-$ final soil water content $[\mathrm{mm}] ; S W_{0}-$ initial soil water content on day $i[\mathrm{~mm}] ; t-$ time [days]; $R_{\text {day }}-$ amount of precipitation on day $i$; $Q_{\text {surf }}$ - amount of surface runoff on day $i ; E_{a}$ - amount of evapotranspiration on day $i$; $W_{\text {seep }}$ - amount of percolation and bypass exiting the soil profile bottom on day $i ; Q_{g w}$-amount of return flow on day $i$.

The SWAT model allows two ways for estimating surface runoff volume. One is using a modification of the SCS curve number method (USDA soil conservation service, 1972) and the second one is the Green \& Ampt infiltration method (Green, Ampt 1911). In the curve number method, the curve number $(C N)$ varies non-linearly with the moisture content of soil. The curve number drops as the soil approaches the wilting point and increases to near 100 as the soil approaches saturation. The $C N$ method has been used extensively for runoff simulations (Geetha et al. 2007; Chung et al. 2010). Moreover, the method chosen to calculate the surface runoff depends also on availability of precipitation data for the chosen basin. In this study, the SCS curve number method has been chosen to compute surface runoff.

In the SWAT model, the soil profile is subdivided into multiple layers to support the process of infiltration, evaporation, plant uptake, lateral flow, and percolation to lower layers. The soil percolation component of SWAT uses a storage routing technique to simulate flow through each soil layer in the root zone. The percolation to lower layers occurs when field capacity of the soil layer is exceeded and layer below is not saturated. Groundwater flow contribution to total stream flow is simulated by routing a shallow aquifer storage component to the stream (Arnold et al. 1998; Abbaspour et al. 2007). Water yield is the total amount of water leaving the HRU and entering the main channel during the time step. It is one of the important components of the water cycle that needs to be estimated for sustainable management of the water resources of the study area (Adeogun et al. 2014). The SWAT model uses the equation (2) to estimates water yield at the basin scale:

$$
W Y L D=S U R Q+L A T Q+G W Q-T L O S S
$$

where: WYLD is the amount of water yield [ $\mathrm{mm} \mathrm{H}_{2} \mathrm{O}$ ]; $S U R Q$ is the surface runoff $\left[\mathrm{mm} \mathrm{H}_{2} \mathrm{O}\right], L A T Q$ is the lateral flow contribution to stream flow $\left[\mathrm{mm} \mathrm{H}_{2} \mathrm{O}\right], G W Q$ is the groundwater contribution to stream flow $\left[\mathrm{mm} \mathrm{H}_{2} \mathrm{O}\right]$ and TLOSS is the transmission loss $\left[\mathrm{mm} \mathrm{H}_{2} \mathrm{O}\right]$ from tributary channels in the HRU via transmission through the bed.
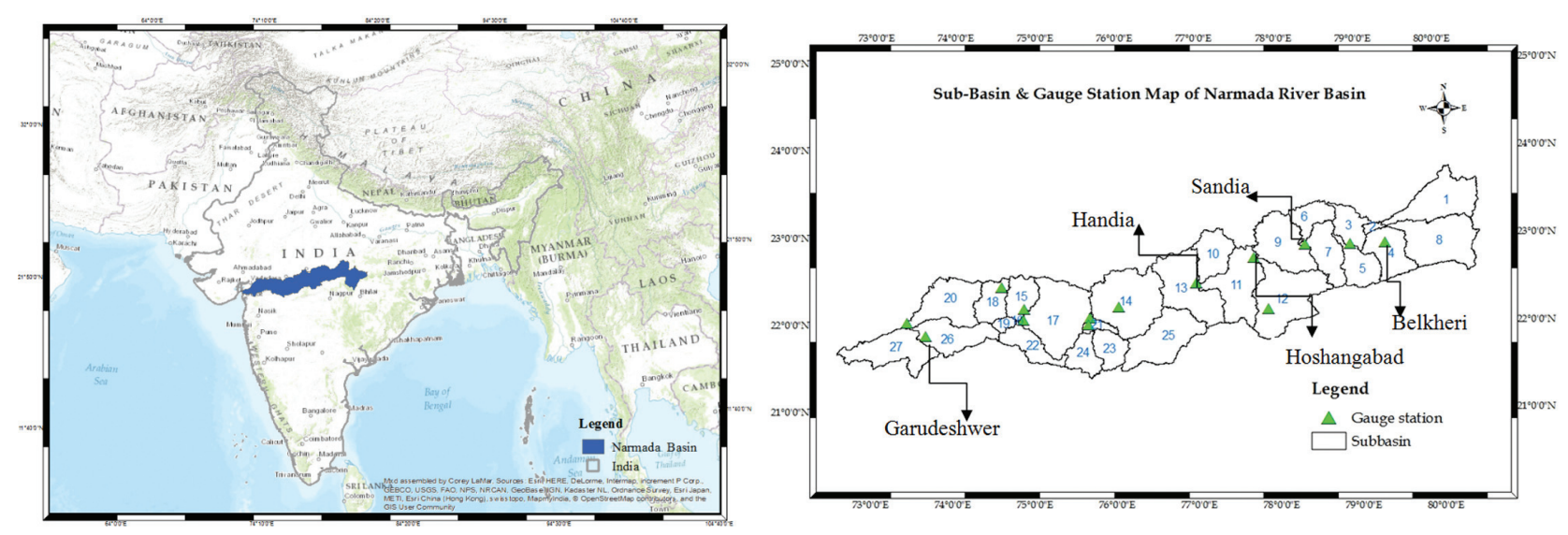

a)

b)

Fig. 1. (a) Location map of the Narmada River basin, (b) sub-basin map of the Narmada River basin 
The SWAT model uses physically based methods that are based on historical weather variables for the computation of PET. These methods include Hargreaves (Hargreaves et al. 1985), Priestley-Taylor (Priestley, Taylor 1972) and Penman-Monteith (Monteith 1965; Allen et al. 1989). The three PET methods included in SWAT vary in the amount of required inputs. The Penman-Monteith method requires solar radiation, air temperature, relative humidity and wind speed. The Priestly-Taylor method requires solar radiation, air temperature and relative humidity. The Hargreaves method requires only air temperature. The Penman-Monteith method is recommended as the sole standard method by FAO (Allen et al. 1998).

The SWAT model in the Arc-GIS setup has been used to delineate the river basin, and the Narmada river basin has been divided into 27 sub-basins based on the elevation value, further the sub-basins were divided into 442 HRUs using the thresholds values $8 \%, 7 \%$ and $5 \%$ of the land use, soil and slope type respectively. The sub-basins and their serial numbers in the model are shown in Fig. $1 b$. The performance of the model in simulating runoff evaluated using the SWAT Calibration and Uncertainty Program (SWAT-CUP), by Abbaspour et al. (2007).

\subsection{Datasets}

The data requirements for the ArcSWAT interface include meteorological variables as well as GIS layers, namely the digital elevation model (DEM), a soil map, and a land use map. For this study, DEM is downloaded from the (http://gdem.ersdac.jspacesystems.or.jp) ASTER global DEM (GDEM) website for the study region. LULC and soil datasets are taken from The Waterbase (http:// waterbase.org/download_data.html). Several global reanalysis projects such as Climate Forecast System Reanalysis (CFSR) from NCEP (Saha et al. 2010) have become available recently. This includes atmospheric analysis data (winds, temperature, humidity, surface pressure etc.) which are available for long period. The CFSR data are based on meteorological model reanalysis, which is a combination of a meteorological model field and surface observations and remote sensing data. Surface parameters (such as precipitation, surface temperatures, ET, PET) in the reanalysis datasets are 6-hrly predictions from the model consistent with atmospheric datasets. In the absence of observed data, these reanalysis datasets can be downscaled to basin, sub-basin and HRU scale to generate a good quality hydrological datasets. The daily observed meteorological variables such as precipitation, wind speed, solar radiation, relative humidity and temperature values from CFSR have been acquired for 30 years (1984-2013) from (http://globalweather.tamu.edu/). Daily discharge data (2001-2008) for five gauge stations are collected from the Central Water Commission (CWC) for calibration and validation of the SWAT model Separate calibration experiments for discharge were carried out using the IMD as well as CFSR precipitation and temperature forcing. The hydrological characteristics of the Narmada River basin was studied by forcing the SWAT model by 30 years of CFSR data.

\subsection{Experiments}

SWAT has the capability to compute water cycle components using a different combination of climatic input variables. In this study, three combinations of input climatic parameters were experimented with. The experiments are explained here in brief.

Experiment-1: In the first experiment, the SWAT model was forced with daily data of all climate variables (precipitation, temperature, winds, solar radiation and relative humidity from CFSR) from 1984 to 2013;

Experiment-2: In this experiment, precipitation, temperature and relative humidity from CFSR from 1984 to 2013 were used. Climatological mean values for winds and solar radiation were used in this experiment instead of CFSR provided daily data;

Experiment-3: In the third experiment, daily CFSR data of only precipitation, temperature and winds were used and climatological mean values for relative humidity and solar radiation were used in this experiment. Before, carrying out these experiments, the model was also forced with observed precipitation as well as CFSR precipitation for the same period ( 8 years) and the skill of the model in simulating discharge using these two precipitation datasets has been evaluated.

\section{Result and discussion \\ 4.1. Calibration and validation}

In order to evaluate the reliability of the SWAT model, the model has been calibrated and validated against observed discharge data for the five stations, namely Balkheri, Sandia, Handia, Hoshangabad and Garudeshwar - using observed runoff data from 2001-2004 and from 2005-2008 respectively. The daily discharge simulations using SWAT CUP with IMD and CFSR rainfall data yielded the following results.

The model is calibrated and validated for Balkheri for the 2001-2004 (Fig. 2a) and 2005-2008 (Fig. 2b) respectively. It can be seen that during calibration, the model underestimates discharge values in 2001 and 2003 with 

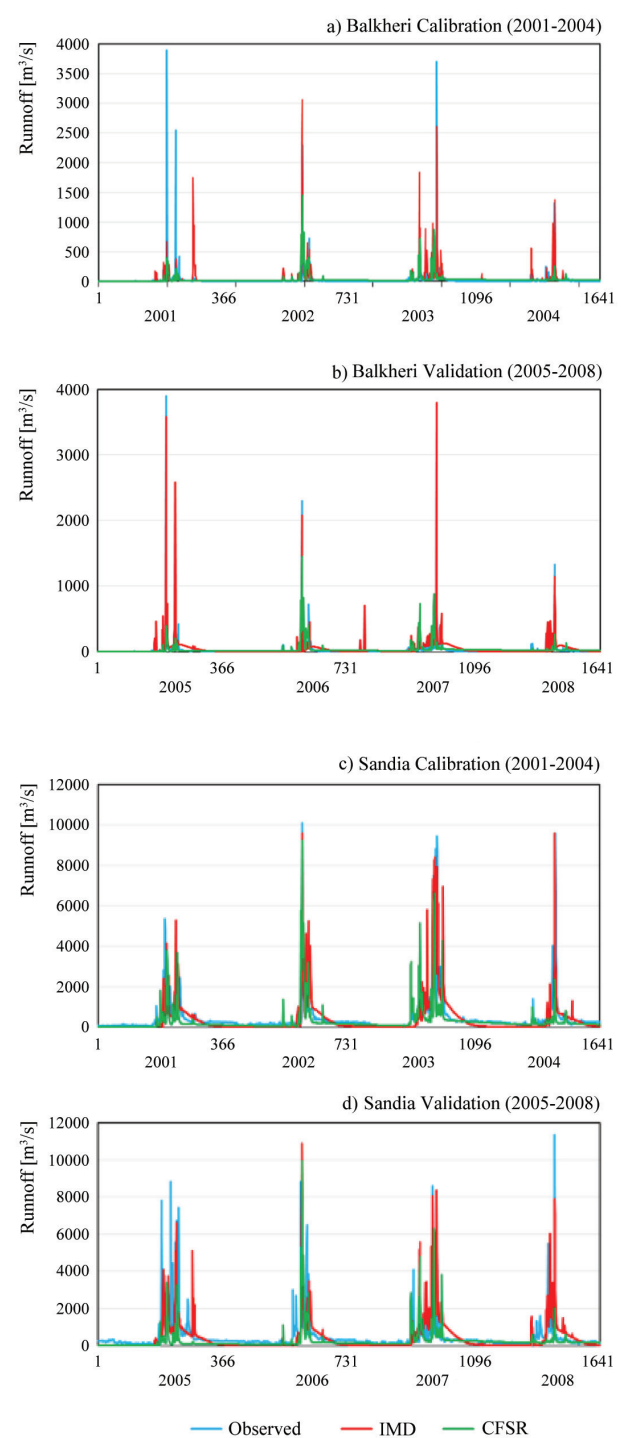

Fig. 2. Calibration and validation of streamflow simulated by the SWAT model with IMD and CFSR precipitation for (a) and (b) Balkheri; (c) and (d) Sandia

IMD data. Overestimation is quite large especially during the year 2002 with IMD rainfall. It can be seen that with CFSR rainfall, the model is not able to capture the variability of discharge in the calibration period (2001-04) as well as the validation period (2005-08). In figure 2c, it can be seen that the model is able to capture the discharge variability well in 2001 and 2002 with CFSR rainfall for Sandia station. It is seen that for the year 2001, IMD rainfall for some events produces discharge which is an underestimate. The peak flow event of 2002 for this station is captured well by the model, but for some events in 2003, the model underestimates the discharge values. For the year 2001 to 2003, yield with CFSR rainfall shows good correlation, while for the 2004, with IMD rainfall, it has a good correlation. In figure $2 \mathrm{~d}$, during validation for Sandia station, it has been noted that the model provides reasonably good result in the years 2004 and 2005 with the CFSR rainfall, but results are not so good for 2006 with
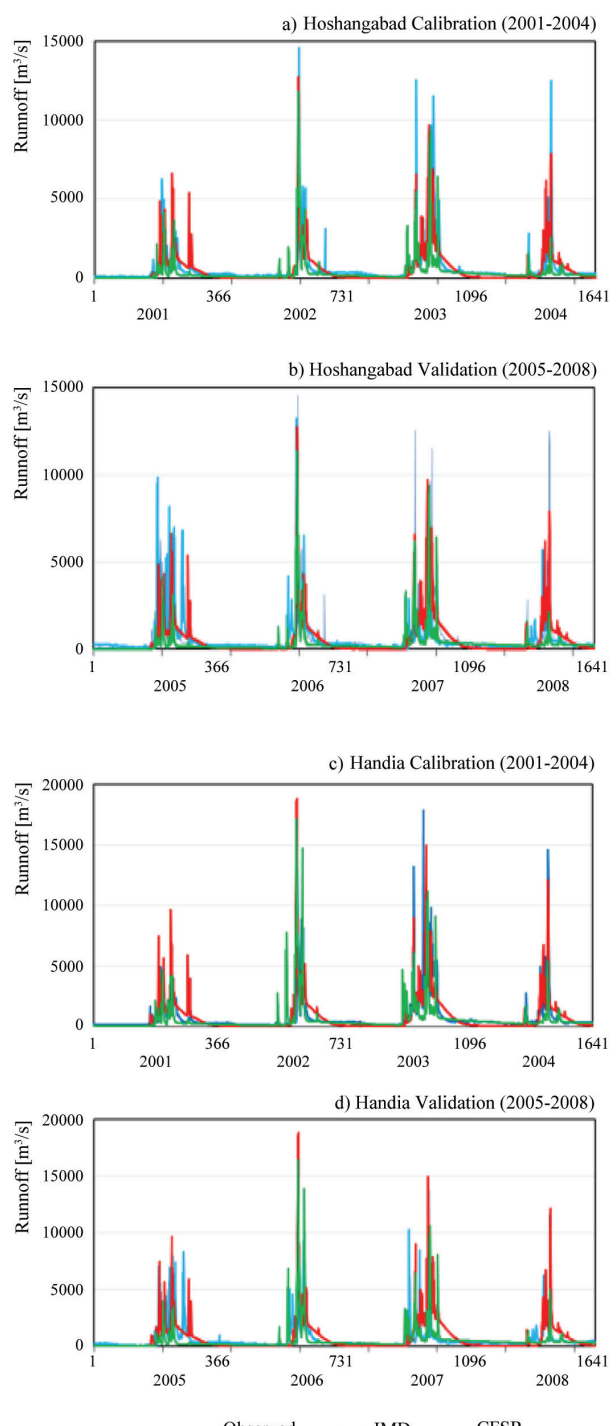

Fig. 3. Same as Fig. 2 but for (a) and (b) Hoshangabad; (c) and (d) Handia

the both CFSR and IMD rainfall data. The model overestimates discharge in 2007 and 2008.

Figure $3 \mathrm{a}$ shows that the simulations are closer to the observations of Hoshangabad gauge station in 2001 for maximum events with the CFSR data. Figure $3 \mathrm{~b}$ shows that the model results are good in 2005 for the CFSR data as compared to IMD rainfall, but there is an underestimation in 2006 for both CFSR and IMD data. In figure $3 \mathrm{c}$ for Handia gauge station it is seen that the model is able to capture peak flow events for the 2002, while the model shows under estimation for the 2003 and 2004. In the validation period for 2006 and 2007, the model shows good results as can be seen in Fig. 3d for Handia station. For the Garudeshwar gauge station, the model overestimates runoff values in all the years with IMD rainfall as well as CFSR. In the validation period, the same trend in simulations is also seen. However, the model underestimates runoff more in 2008 with the IMD rainfall when compared to CFSR rainfall (figure not shown). 
The performance of the model in SUFI-2 was evaluated using Nash-Sutcliffe (NS), Nash and Sutcliffe (1970), as the objective function. $P$-factor, $R$-factor, coefficient of determination $R^{2}$ and $N S$ (shown in equation 3 and 4) were used as skill metrics for evaluation. $P$-factor and $R$-factor play an important role in evaluating model calibration and prediction uncertainty, $P$-factor is the percentage of measured data bracketed by the $95 \%$ prediction uncertainty (95PPU) and it should to reach near $100 \%$ for best simulation (Notter et al. 2012). An $R$-factor closer to 1 means the model predictions are more accurate (Abbaspour et al. 2007).

$$
\begin{gathered}
N S=1-\frac{\sum_{i}\left(Q_{m}-Q_{s}\right)_{i}^{2}}{\sum_{i}\left(Q_{m, i}-\bar{Q}_{m}\right)^{2}} \\
R^{2}=\frac{\left[\sum_{i}\left(Q_{m, i}-\bar{Q}_{m}\right)\left(Q_{s, i}-\bar{Q}_{m}\right)\right]^{2}}{\sum_{i}\left(Q_{m, i}-\bar{Q}_{m}\right)^{2} \sum_{i}\left(Q_{s, i}-\bar{Q}_{m}\right)^{2}}
\end{gathered}
$$

where subscripts $m$ and $s$ represent measured and simulated, respectively, $\bar{Q}_{m}$ is the average of measured data, and $i$ the simulation data of runoff in $i$ day.

The calibration and validation statistics of discharge simulated by the model forced with IMD rainfall are shown in table 1. During calibration period, Balkheri and Sandia stations show reasonably good skill (NSE $>0,6)$. Hoshangabad has NSE value of 0,45 . Skill for the Garudeshwar station has comparatively less NSE. The skill drops down significantly during validation period with Balkheri and Sandia having NSE values of 0,45 and 0,25 respectively. Therefore, it is seen that for Garudeshwar (a downstream gauge station), the simulated runoff does not agree well with observations. Observed discharge in downstream depends on timing and amount of water release from reservoirs and dams located upstream. In the present study, water release data from the reservoir located upstream of Garudeshwar has not been taken into account. It is also seen that validation skill depends on the characteristics of rainfall during the calibration years. When the model is calibrated for the years 2001 to 2004, this period has two drought years while the validation period from 2005

Table 1. Calibration and validation statistics of discharge simulation for the five gauge stations in the Narmada River basin

\begin{tabular}{|l|c|c|c|c|}
\hline \multirow{2}{*}{ Stations name } & \multicolumn{2}{|c|}{$\begin{array}{c}\text { Calibration } \\
(2001-04)\end{array}$} & \multicolumn{2}{c|}{$\begin{array}{c}\text { Validation } \\
(2005-08)\end{array}$} \\
\cline { 2 - 5 } & $R^{2}$ & $N S E$ & $R^{2}$ & $N S E$ \\
\hline Balkheri & 0,79 & 0,75 & 0,6 & 0,45 \\
\hline Sandia & 0,70 & 0,67 & 0,39 & 0,25 \\
\hline Handia & 0,42 & 0,32 & 0,43 & 0,21 \\
\hline Hoshangabad & 0,50 & 0,45 & 0,33 & 0,23 \\
\hline Garudeshwar & 0,54 & 0,16 & 0,25 & 0,19 \\
\hline
\end{tabular}

to 2008 does not have any. Therefore, validation skill for all the stations are less than those of calibration period. Similar statistics have been obtained with the use of CFSR rainfall (not shown in table). As the CFSR rainfall is model generated, there are obvious differences between the IMD observed rainfall and CFSR rainfall. This leads to marginal reduction of skill when CFSR rainfall is used as compared to IMD rainfall data.

\subsection{Water cycle components}

Simulations of the water cycle components using the three combinations of input climatic parameters show the following results.

\subsubsection{Annual mean climatology}

Information on water cycle components such as groundwater, surface water, PET, percolation etc. at subbasin scale is limited. Hydrological models have the capability to simulate vertical and horizontal groundwater movements with discredited cells (e.g. Siebert et al. 2010; Wada et al. 2010), which then provides estimates of storage change. 30-years of annual mean climatology of model simulated ET, PET and surface runoff are shown in Fig. 4 (a-c). Similar plots for water yield, percolation and groundwater are shown in Fig. 5 (a-c). These are from the Experiment-1 simulations in which all the forcing terms as explained earlier) have been used from CFSR data. Similar results from Experiment-2 and Experiment-3 are not shown in figures.

Estimation of basin-wise spatial variation of ET is important in order to understand interactions between water cycle and energy transport in the biosphere, hydrosphere, and atmosphere. In the present study, spatial variation of ET in the Narmada basin is prominent and ranges from $387 \mathrm{~mm} /$ year to $551 \mathrm{~mm} /$ year for Experiment-1 (ET-1). For Experiment-2 (ET-2) and Experiment-3 (ET-3) range from $367 \mathrm{~mm} /$ year to $533 \mathrm{~mm} /$ year $350 \mathrm{~mm} /$ year to $515 \mathrm{~mm} /$ year respectively (not shown in figure). While most of the sub-basins have ET within $390 \mathrm{~mm} /$ year to $420 \mathrm{~mm} /$ year, few sub-basin especially in the eastern part of the basin have $E T$ values of more than $420 \mathrm{~mm} /$ year as seen in Fig. 4a. Annual mean climatology of PET for Experiment-1 (PET-1) also has a large spatial variation from sub-basin to sub-basin. From figure $4 \mathrm{~b}$ it can be seen that $P E T$-1 values increase from east to west and its distribution varies from 1957 to $2471 \mathrm{~mm} /$ year. For Experiment-2 and Experiment-3 (not shown in figure) PET-2 variation is from 1758 to $2291 \mathrm{~mm} /$ year and PET-3 is from value 1720 to $2274 \mathrm{~mm} /$ year within the basin 

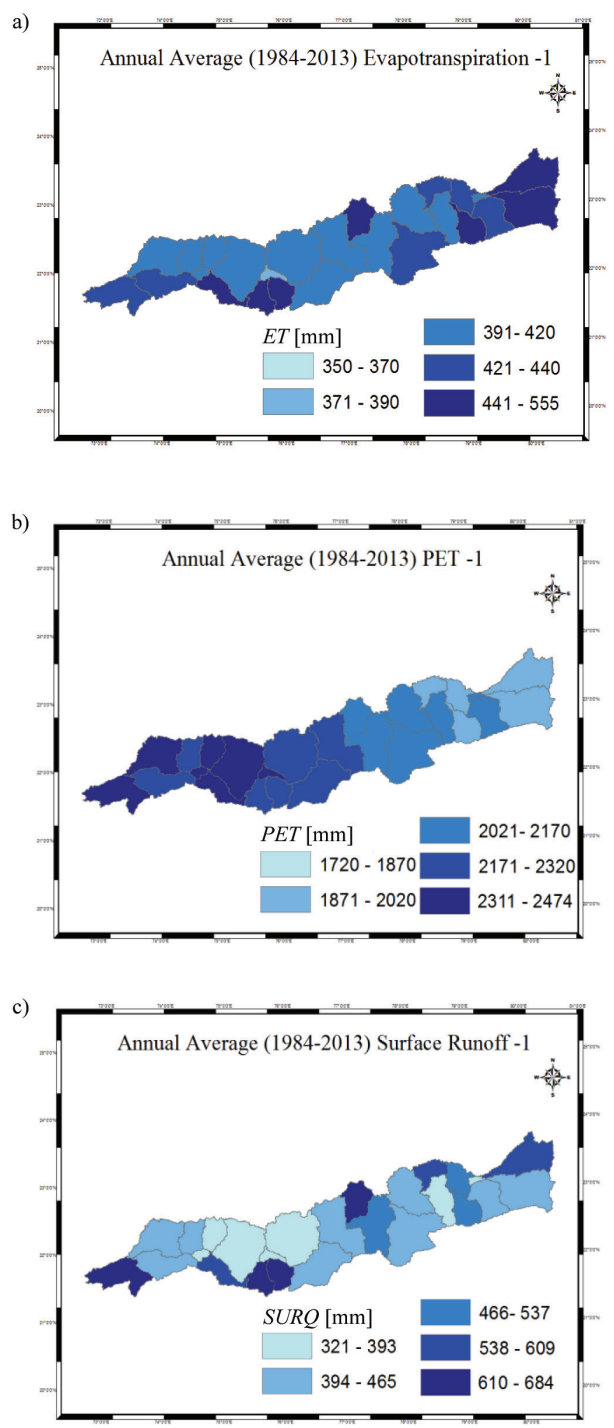

Fig. 4. Annual average of sub-basin wise distribution of model simulated (a) ET, (b) PET and (c) surface runoff; the averaging has been done for all the years from 1984-2013

respectively. Surface runoff is the flow of water that takes places after excess storm water, melt water, or other sources flow over the earth's surface. There are no large variations among the simulated runoff from different experiments. Figure $4 \mathrm{c}$ shows the spatial distribution of annual mean surface runoff over the Narmada River basin for Experiment-1. Mathematical models have better reliability for runoff assessment as this is less data driven, simpler to formulate and cheaper to compute (Fontaine et al. 2002). In the present study the surface runoff pattern has very good agreement with the rainfall pattern. As all the experiments provide the same spatial pattern, it may be concluded that precipitation is the most important parameter for computing surface runoff and that relative humidly and solar radiation don't have a significant impact on surface runoff.

Water Yield is defined as the average amount of fresh water that runs off within an unregulated watershed.
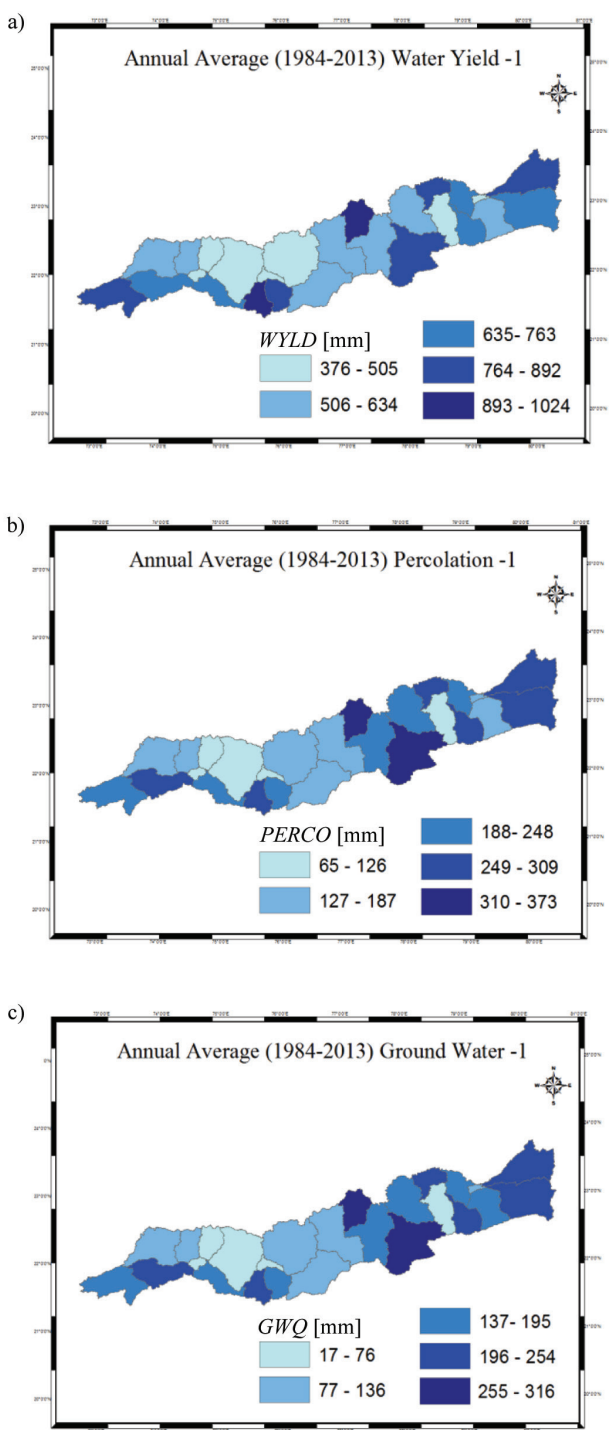

Fig. 5. Annual average of sub-basin wise distribution of model simulated (a) Water yield (b) percolation and (c) ground water; the averaging has been done for all the years from 1984-2013

In the present study, simulated water yield slightly increases from Experiment-1 (water yield-1) with values of $376 \mathrm{~mm} /$ year to $983 \mathrm{~mm} / \mathrm{year}$ in various sub-basins (Fig. 5a) to $410 \mathrm{~mm} /$ year to $1024 \mathrm{~mm} /$ year in the third experiment (water yield-3, not in figure) Percolation is a hydrologic measure of the water volume that is able to infiltrate into the soil past the root zone to recharge the shallow and/or deep water aquifers (Miller et al. 2002). Precipitation creates runoff that passes over the ground surface and helps to fill water bodies. It also percolates or moves downward through openings in the soil to replenish aquifers under the ground. Figure $5 \mathrm{~b}$ shows the estimated annual mean percolation from Experiment-1. This parameter depends on the soil properties of the basin and rainfall. When this parameter is estimated using three different combinations of climatic input variables, the magnitude of percolation in Experiment-1 (Percolation-1) varied from 65 to $350 \mathrm{~mm} /$ year (Fig. 5b), percolation-2 ranged from 
71 to $359 \mathrm{~mm} /$ year and percolation-3 had values between 85 to $373 \mathrm{~mm} /$ year in different sub-basins (not shown in figures). Groundwater originates from precipitation that percolates into the ground. It is the component of water cycle that flows underground. The spatial distribution of groundwater yield across the river basin is shows in figure 5c. The SWAT model calculates the soil water balance on a daily basis. The model updates daily the quantity of water accumulated in every soil layer for every HRU (Vazquez-Amábile, Engel 2005). However soil water content is an output variable for the soil profile as a whole, not for every layer. Similar to the surface runoff, groundwater also follows the pattern of rainfall over the whole study (1984-2013), as shown in Fig. 5c.

\subsubsection{Annual cycle of hydrological parameters}

In order to further understand the variability and spatial distribution of water cycle components in the Narmada basin, the climatological annual cycle of various water cycle parameters has been examined. Five sub-basins have been chosen for this detailed analysis. These sub-basins are spread across the basin and have been marked in Fig. $1 \mathrm{~b}$ as sub-basin numbers 1, 7, 10, 15 and 21. The climatological
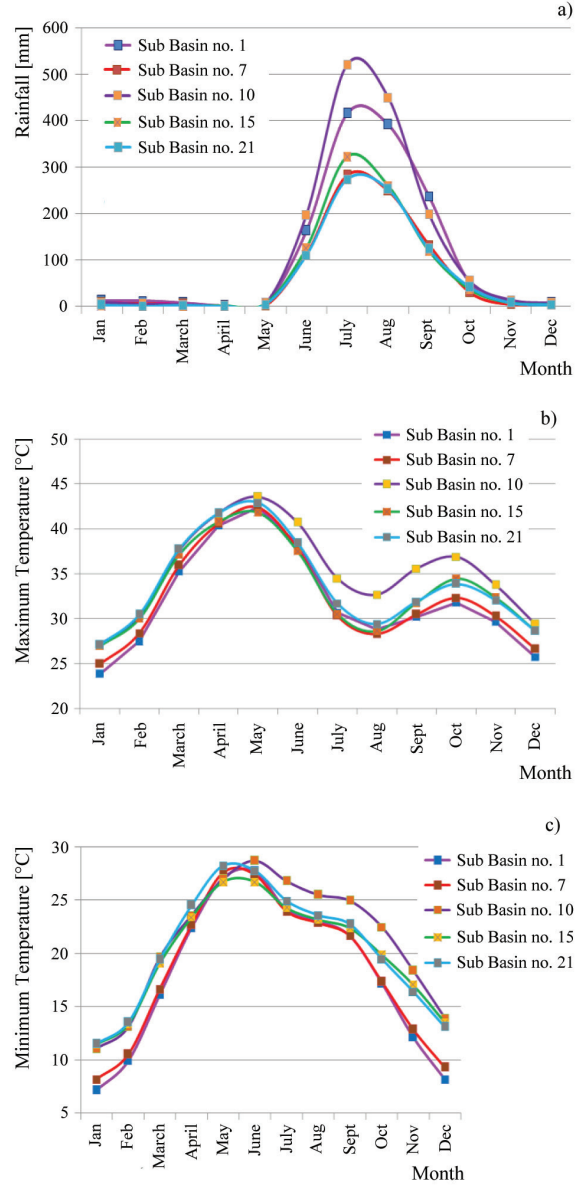

Fig. 6. Climatological annual cycle of CFSR (a) rainfall, (b) maximum temperature and (c) minimum temperature annual cycle of rainfall, maximum and minimum temperature (used to force the SWAT model) for these five subbasins are shown in Fig. 6. Precipitation plot (Fig. 6a) shows that the Narmada basin receives rainfall only during the summer monsoon season (June to September). There is large variability in rainfall revived in various basins. Subbasin number-10, in the central north of the basin receives maximum rainfall (more than $500 \mathrm{~mm}$ ) compared with sub-basin number-21, on the western side of the basin, which receives less than $200 \mathrm{~m}$ of rainfall per year. Such spatial variability in rainfall gives rise to spatial variability of other hydrological variables as seen in Fig. 4 and 5. The climatological annual cycle of maximum and minimum temperatures of the five sub-basins are shown in Fig. $6 \mathrm{~b}$ and $6 \mathrm{c}$ respectively. Both maximum and minimum temperatures have two maxima in their annual cycle. The peak is seen in the month of May and maximum temperature is more than $40^{\circ} \mathrm{C}$. A secondary peak is seen in October when the monsoon has withdrawn and the sky is mainly clear. Sub-basin number-10 is the warmest in summer (May) as well as in post-monsoon season.

When the SWAT model is run for 30 years, forcing it with the rainfall and temperatures having the annual cycle as shown in Fig. 6, the climatological annual cycle of other
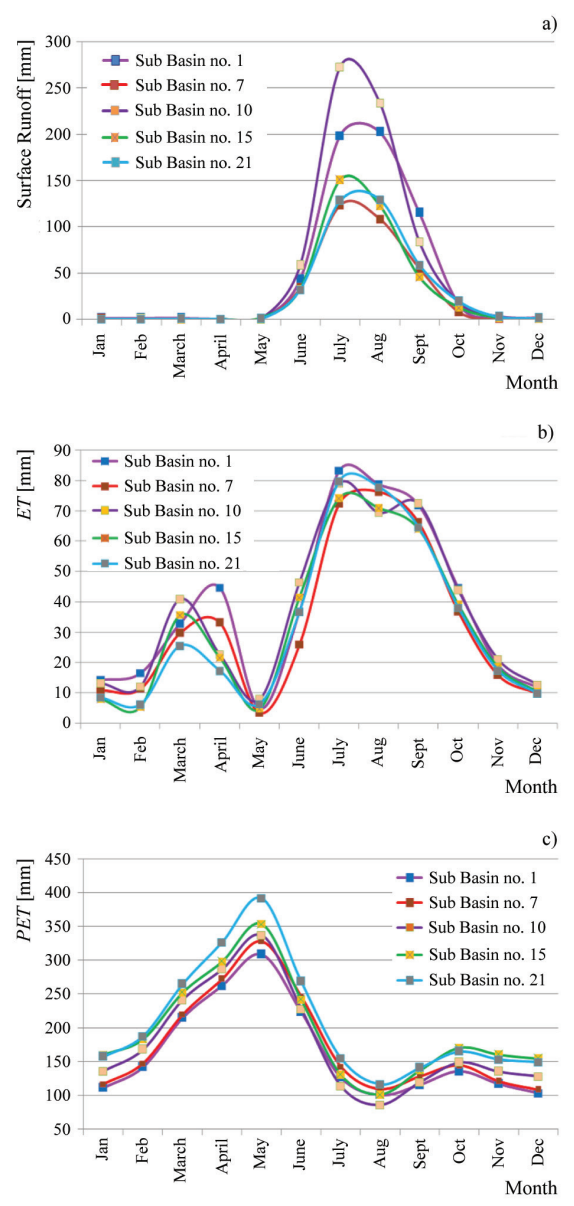

Fig. 7. Climatological annual cycle of model simulated (a) surface runoff; (b) $E T$ and (c) PET 

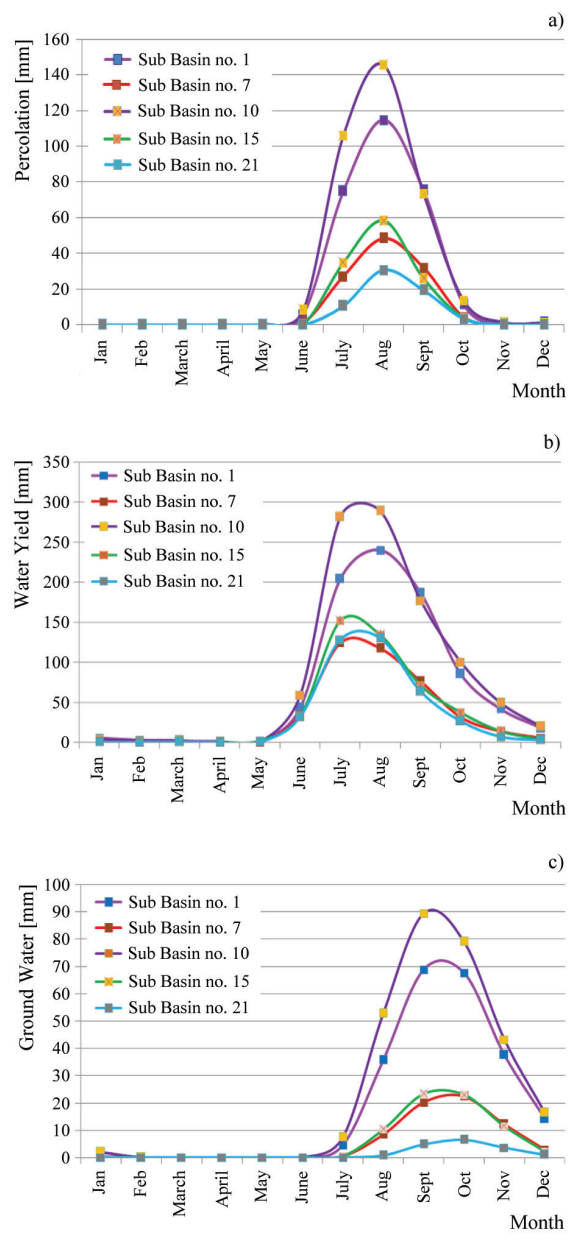

Fig. 8. Climatological annual cycle of model simulated (a) percolation, (b) water yield and (c) ground water

hydrological parameters follow the pattern of the forcing parameters (rainfall and temperatures). The climatological annual cycle of runoff, ET and PET are shown in Fig. 7. These are for the five selected sub-basins described earlier. Maximum surface runoff occurs from all the sub-basins in the month of July. Sub-basin number-10 has maximum runoff when compared to other basins. The surface runoff from this basin is about $280 \mathrm{~mm}$. Sub-basins number-7 and 21 contribute a much lower amount (less than $150 \mathrm{~mm}$ ) to the river basin in terms of surface runoff (Fig. 7a). Evapotranspiration $(E T)$ has two broad peaks in its annual cycle (Fig. 7b). One peak is in the months of March or April and the other peak is in August. Sub-basins number 1 and 7 have a peak in April while other sub-basins have peaks in March. Maximum ET is simulated in the months of July and August. As the temperature rises in March or April, ET starts to build up in the basin. As summer peaks in, soil becomes too dry and no evaporation is simulated. Therefore, there is a minima in the month of May in all the sub-basins. As $E T$ is a function of land use and land cover, depending on the vegetation patterns in various subbasins, it has some differences in its annual cycle from sub-basin to sub-basin. PET has maximum values for each sub-basin in the month of May and has the lowest magnitude in August as seen in Fig. 7c. It is seen that the PET values are much lower during monsoon seasons and it slightly increases during the post monsoon season.

The percolation of water into the soil sub-surface depends on soil type as well as the surface water available on the soil surface. The climatological annual cycle of percolation for the selected sub-basins shown in Fig. 8a indicates that other than the monsoon months, percolation is zero over the entire basin. Percolation is maximum in the month of August, however, there is large variations in percolation values among sub-basins. While sub-basin number 10 has maximum of more than $140 \mathrm{~mm}$ percolation, the sub-basin number 21 has only about $30 \mathrm{~mm} / \mathrm{yr}$. Total water yield also has similar variations among subbasins as seen in its annual cycle plot in Fig. 8b. While most of the sub-basins have maxima in July, some have maxima in August. The percolation of surface water into the ground is used to charge the groundwater. Sub-basin wise groundwater values have also been examined. The contribution of rainfall into the annual cycle of groundwater for the five sub-basins is shown in Fig. 8c. A delayed response of groundwater to precipitation and percolation is clearly seen in the figure. For most of the sub-basins, the maximum contribution to groundwater is in September, while for some, it is in October. Sub-basin number 10 has maximum groundwater which is about $90 \mathrm{~mm} /$ year while sub-basin number 21 has the lowest value of about $10 \mathrm{~mm} /$ year.

\subsubsection{Interannual Variability of the Water Cycle}

Rainfall over the Narmada basin has considerable interannual variability (Sharma et al. 2015) due to year-to-year variations in rainfall during monsoon seasons. When this variable rainfall is provided as input to the SWAT model, the water cycle components also exhibit large variability on an interannual timescale. Therefore, it is important to examine how the interannual variability of rainfall influences the water cycle components and to identify which other climate variable is also important. Therefore, model simulations of these components from the three experiments described earlier have also been analysed.

Figure 9a shows the year-wise variations of surface runoff (SURQ) over the Narmada basin from the SWAT model for 30 years. Rainfall forcing from CFSR is also plotted on the same figure. From the figure, it can be seen that runoff follows the pattern of rainfall. The years with high rainfall are 1990, 1994, 2008 and 2012. In these years, surface runoff is also quite large. It is seen that there is no large variation in runoff in the three experiments - 
this indicates that winds, humidity or solar radiation have no role to play in surface runoff computation as expected.

Figures $9 \mathrm{~b}$ and $9 \mathrm{c}$ show the interannual variation of simulated ET and PET during the period 1984-2013 for the Narmada River basin respectively. Rainfall forcing from CFSR is also shown in the figure. It is found that in some years, ET increases as the rainfall increases. However, there is no one-to-one relation. Surface temperature variations are also important for this component of the water cycle. Warmer temperatures increase the rate of evaporation of water into the atmosphere, in effect increasing the atmosphere's capacity to "hold" water (Karl et al. 2009). There are also variations among experiments. This indicates that surface winds, relative humidity and solar radiation modify the ET and PET. It is well known that ET and PET depend on wind speed as well as relative humidity. As the cropping pattern or land use pattern is different from sub-basin to sub-basin, as well the fact that plants transpire based on the leaf area index and available photo-synthetically active solar radiation, if accurate information on these three parameters are not provided, ET and PET computations will not be correct. ET from experiment-1 (ET-1) has a higher value when compared
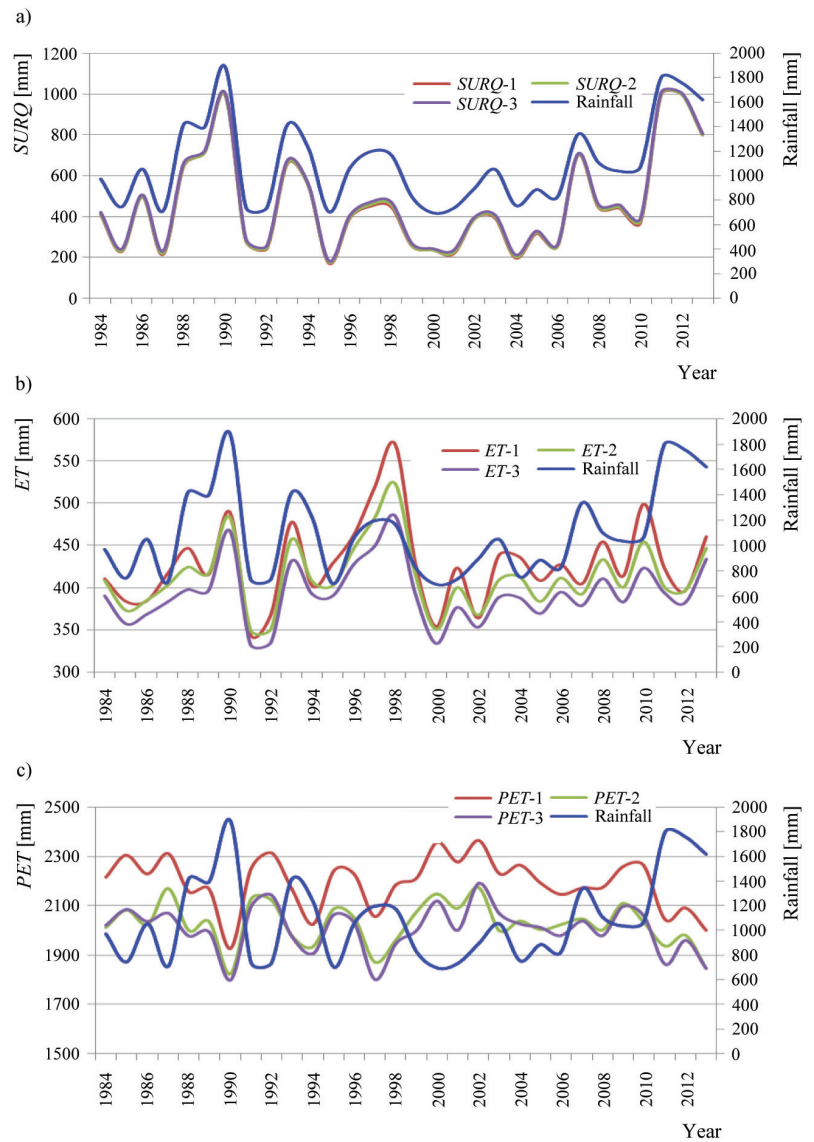

Fig. 9. Interannual variations in annual average of model simulated (a) surface runoff, (b) ET and (c) PET from the three sensitivity experiments. Input CFSR rainfall is also shown in the figure to ET-3 as ET-1 computation uses additional climate input (solar radiation and relative humidity).

Year-wise variations of percolation, groundwater and water yield for the five sub-basins are shown in Fig. 10 (a, b, c) respectively. These parameters have been estimated using the three combination climate variables as described earlier. Figure 10a clearly shows that percolation over all the years follows the pattern of rainfall. If the rainfall is greater, (e.g. in year 1990, rainfall is $1888 \mathrm{~mm} /$ year) percolation is also greater. Experiment-3 (PERC-3) shows a higher amount for all the years when compared to the other two experiments (PERC-2 and PERC-1). It was earlier seen that when all the climate parameters are used to estimate ET, the maximum was obtained when compared to the other two experiments. If a greater amount of water is evaporated from the surface, a smaller amount of water is available for percolation in to the soil. This feature is clearly brought out in the SWAT model simulations and PERC-3 has higher percolation values in each year than PERC-1. As a result, for Experiment-3, groundwater as well as water yield is also more in Experiment-3 for each year when compared to Experiment-1 or Experiment-2. This feature is clearly
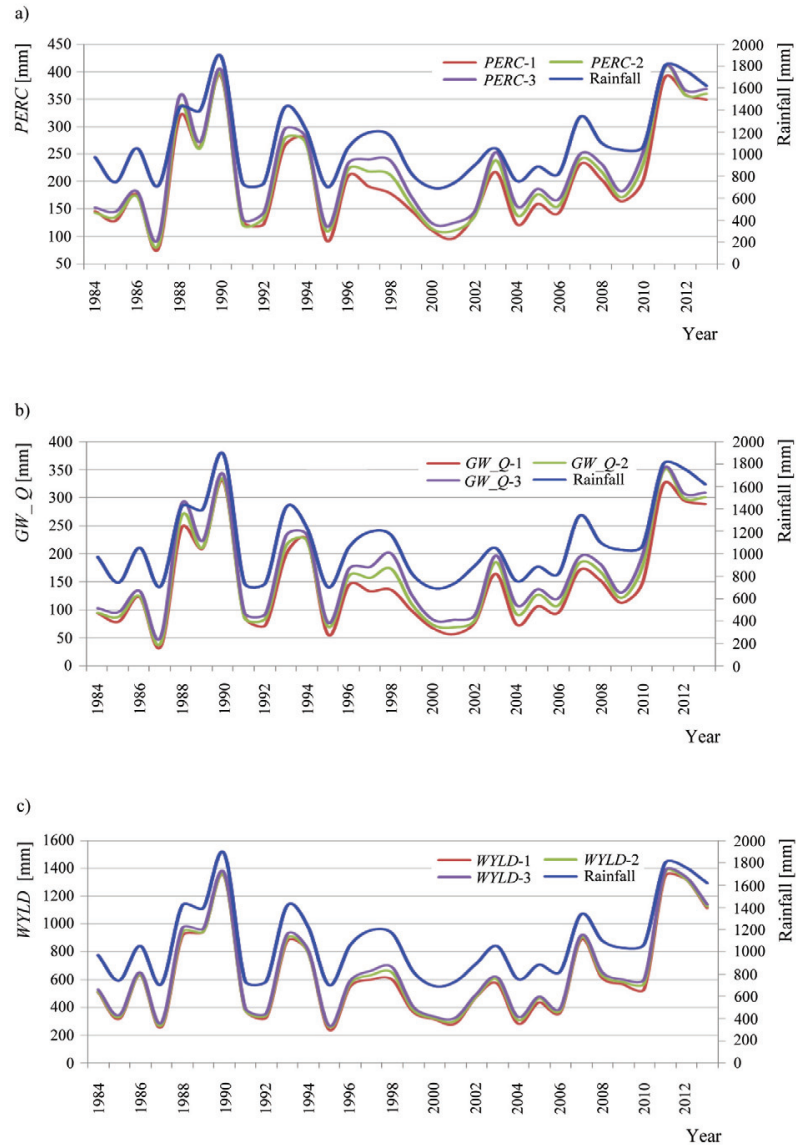

Fig. 10. Interannual variations in annual average of model simulated (a) percolation, (b) ground water and (c) water yield from the three sensitivity experiments. Input CFSR rainfall is also shown in the figure 
brought out in the plot of year-wise variation of groundwater and water yield shown in Fig. $10 \mathrm{~b}$ and $10 \mathrm{c}$ respectively. However, it may be noted that for all the components of the water cycle, rainfall is the key forcing and inter annual variation of these parameters is strongly linked to rainfall variability.

\subsubsection{Water balance}

The water balance study permits us to inspect the water cycle for any period of time. Water balance can be computed for any river basin by calculating the total precipitation input and total ways of outputs. Water balance describes the various ways in which the water supply is expended and it is defined by the water balance equation:

$$
P=Q+E T+d S / d t
$$

where: $P$ - precipitation $[\mathrm{mm}] ; Q-$ runoff $[\mathrm{mm}] ; E T-$ evapotranspiration; $d S / d t$ - storage per time step [mm].

For the Narmada River basin, water balance has been computed using the equation 5 in a different climatic input variable manner, as shown in Fig. 11. The water storage (or residual) computed from the water balance using the SWAT model has both positive and negative values indicating a surplus or deficit of water in the Narmada basin. However, in most of the years, the residual water is much lower (about 5 to $15 \mathrm{~mm} /$ year). This shows that the model computed the water cycle components are in hydrological balance. There are two years in the study period, when a large residual is noticed. In 1997 the residual term is more than $30 \mathrm{~mm}$, while in 1998, it is less than $20 \mathrm{~mm}$. It has been observed that the water balance is dramatically increased in 1997 and reversely decreased in 1998. Though this amount is still too low in terms of the range of all the water cycle components in a yearly basis, more detailed analysis of the surface water budget is necessary to explain this. This is being carried out in terms of each sub-basin and HRU-wise.

\section{Conclusion}

There is inadequate understanding of the hydrological cycle due to lack of observations at river basin scale. Numerical models have a limited ability to simulate various hydrological processes and their associated feedbacks leading to large uncertainties in the quantification of the hydrological cycle. In this study, the SWAT model has been used to compute the water cycle components (evapotranspiration, potential evapotranspiration, surface runoff, percolation, groundwater flow and water yield)

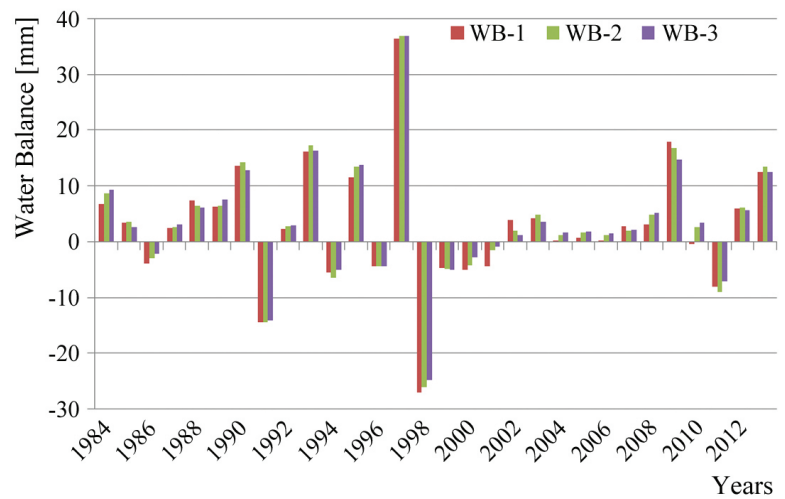

Fig. 11. Interannual variation of the annual average water balance of Narmada River basin

using the three combinations of climatic input parameters. The model was forced with observed rainfall data as well as CFSR rainfall data to calibrate the discharge simulated by the model. Observed discharge data at various gauge stations on the Narmada River were used. It was found that the SWAT model has reasonable skill when the model is forced with either observed gridded rainfall or the CFSR rainfall. In order to examine the spatial and temporal variability of the water cycle components in the Narmada basin, the SWAT model was run for 30 years at a daily time-scale using CFSR precipitation, temperature, humidity, winds and solar radiation. The following are the main findings of the present study.

- There is large variation in hydrological parameters simulated by the model from basin to basin and year to year. These components are also sensitive to the application of climatic forcing.

- Evapotranspiration increases when all the climatic parameters are used, which then reduces the water availability on the surface for percolation and groundwater recharge.

- However, rainfall is the key parameter which decides the hydrology in the Narmada River basin. During the monsoon seasons, surface runoff is maximum but during other seasons, almost no surface runoff is seen as there is almost no rain.

- Groundwater increase is seen after about one month of rainfall peaks in the basin. Evapotranspiration has two peaks, one in March-April and other in August. Much less evaporation takes place in the basin in the month of May.

- The SWAT model has been able to compute water balance at basin scale and the monthly average of the last 30 years (1984-2013) of the water cycle component at the analysed sub-basin scale. 
Bibliography

Abbaspour K.C., Yang J., Maximov I., Siber R., Bogner K., Mieleitner J., Zobrist J., Srinivasan R., 2007, Modelling hydrology and water quality in the pre-alpine/alpine Thur watershed using SWAT, Journal of Hydrology, 333 (2-4), 413-430, DOI: 10.1016/j.jhydrol.2006.09.014

Adeogun A.G., Sule B.F., Salami A.W., Daramola M.O., 2014, Validation of SWAT model for prediction of water yield and water balance: case study of upstream catchment of Jebba dam in Nigeria, International Journal of Mathematical, Computational, Physical and Computer Engineering, 8 (2), 264-270

Allan R.P., Liepert B.G., 2010, Anticipated changes in the global atmospheric water cycle, Environmental Research Letters, 5 (2), DOI: 10.1088/1748-9326/5/2/025201

Allen R.G., Jensen M.E., Wright J.L., Burman R.D., 1989, Operational estimate of reference evapotranspiration, Agronomy Journal, 81, 650-662

Allen R.G., Pereira L.S., Raes D., Smith M., 1998, Crop evapotranspiration - Guidelines for computing crop water requirements, FAO Irrigation and Drainage Paper, 56, FAO, Rome, Italy, available at http://www.fao.org/docrep/X0490E/ X0490E00.htm (data access 22.08.2017)

Arnold J.G., Srinivasan R., Muttiah R.S., Williams J.R., 1998, Large-area hydrologic modeling and assessment: Part I. Model development, Journal of the American Water Resources Association, 34 (1), 73-89, DOI: 10.1111/j.17521688.1998.tb05961.x

Bastidas L.A., Gupta H.V., Hsu K.-L.,Sorooshian S., 2003, Parameter, structure and model performance evaluation for land-surface schemes, [in:] Calibration of watershed models, Q. Duan, H.V. Gupta, S. Sorooshian, A. Rousseau, R. Turcotte (eds.), American Geophysical Union, Washington, D.C., DOI: 10.1029/WS006p0229

Brutsaert W., Parlange M.B., 1998, Hydrologic cycle explains the evaporation paradox, Nature, 396, 30, DOI: 10.1038/23845

Chung W.H.,. Wang I.T, Wang R.Y., 2010, Theory-based SCS$\mathrm{CN}$ method and its applications, Journal of Hydrologic Engineering, 15 (12), 1045-1058, DOI: 10.1061/(ASCE) HE.1943-5584.0000281

Earls J., Dixon B., 2008, A comparison of SWAT model-predicted potential evapotranspiration using real and modeled meteorological data, Vadose Zone Journal, 7 (2), 570-580

Fontaine T.A., Cruickshank T.S, Arnold J.G., Hotchkiss R.H., 2002, Development of a snowfall-snowmelt routine for mountainous terrain for the soil water assessment tool (SWAT), Journal of Hydrology, 262 (1-4), 209-223, DOI: 10.1016/S0022-1694(02)00029-X

Geetha K.,. Mishra S.K, Eldho T.I., Rastogi A.K., Pandey R.P., 2007, Modification to SCS-CN method for long-term hydrologic simulation, Journal of Irrigation and Drainage Engineering, 133 (5), 475-489, DOI: 10.1061/(ASCE)07339437(2007)133:5(475)

Green W.H., Ampt G., 1911, Studies of soil physics. Part I: The flow of air and water through soils, Journal of Agricultural Science, 4 (1), 1-24, DOI: 10.1017/S0021859600001441

Hargreaves G.L., Hargreaves G.H., Riley J.P., 1985, Agricultural benefits for Senegal River basin, Journal of Irrigation and Drainage Engineering, 111 (2), 113-124, DOI: 10.1061/ (ASCE)0733-9437(1985)111:2(113)

Huntington T.G., 2006, Evidence for intensification of the global water cycle: review and synthesis, Journal of Hydrology, 319 (1-4), 83-95, DOI: 10.1016/j.jhydrol.2005.07.003

IPCC, 2001, Climate change 2001: Synthesis report, Contribution of Working Groups I, II, and III to the Third Assessment Report of the Intergovernmental Panel on Climate Change, R. Watson and the Core Writing Team (eds.), Cambridge University Press, 148 pp.

Jain S.K., Storm B., Bathurst J.C., Refsgaard J.C., Singh R.D., 1992, Application of the SHE to catchments in India. Part 2. Field experiments and simulation studies with the SHE on the Kolar subcatchment of the Narmada River, Journal of Hydrology, 140 (1-4), 25-47, DOI: 10.1016/0022-1694(92)90233-L

Karl T.R., Melillo J.M., Peterson T.C. (eds.), 2009, Global Climate Change Impacts in the United States, A State of Knowledge from the U.S. Global Change Research Program, Cambridge University Press, New York, NY, USA, 188 pp., available at https://downloads.globalchange.gov/usimpacts/ pdfs/climate-impacts-report.pdf (data access 22.08.2017)

Kleinn J., Frei C., Gurtz J., Lüthi D., Vidale P.L., Schär C., 2005, Hydrologic simulations in the Rhine basin driven by a regional climate model, Journal of Geophysical Research, 110 (D4), DOI: 10.1029/2004JD005143

Liepert B.G., Previdi M., 2009, Do models and observations disagree on the rainfall response to global warming?, Journal of Climate, 22, 3156-3166, DOI: 10.1175/2008JCLI2472.1

Manaswi C.M., Thawait A.K., 2014, Application of soil and water assessment tool for runoff modeling of Karam River basin in Madhya Pradesh, International Journal of Scientific Engineering and Technology, 3 (5), 529-532

Mehran A., AghaKouchak A., Phillips T.J., 2014, Evaluation of CMIP5 continental precipitation simulations relative to satellite-based gauge-adjusted observations, Journal Geophysical Research. Atmospheres, 119 (4), 1695-1707, DOI: 10.1002/2013JD021152

Miller S.N., Kepner W.G., Mehaffey M.H, Hernandez M., Miller R.C., Goodrich D.C., Devonald F.K., Heggem D.T., Miller W.P., 2002, Integrating landscape assessment and hydrologic modeling for Land Cover change analysis, Journal of the American Water Resources Association, 38 (4), 915-929, DOI: 10.1111/j.1752-1688.2002.tb05534.x 
Monteith J.L., 1965, Evaporation and environment, [in:] The State and Movement of Water in Living Organisms, Symposia of the Society for Experimental Biology, G.E. Fogg (ed.), Cambridge University Press, XIX, 205-23

Music B., Caya D., 2009, Investigation of the sensitivity of water cycle components simulated by the Canadian regional climate model to the land surface parameterization, the lateral boundary data, and the internal variability, Journal of Hydrometeorology, 10, 3-21, DOI: 10.1175/2008JHM979.1

Nash J.E., Sutcliffe J.V., 1970, River flow forecasting through conceptual models. Part I: A discussion of principles, Journal of Hydrology, 10 (3), 282-290, DOI: 10.1016/00221694(70)90255-6

Nearing M., Liu B., Risse L., Zhang X., 1996, Curve number and Green-Ampt effective hydraulic conductivities, Journal of the American Water Resources Association, 32 (1), 125-136, DOI: $10.1111 / j .1752-1688.1996 . t b 03440 . x$

Netnapa Pongpetch, Pongthep Suwanwaree, 2013, Simulation of stream flow for Upper Lam Takongsub-Watershed using SWAT model, International Journal of Environmental Science and Development, 4 (3), 261-263, DOI: 10.7763/IJESD.2013. V4.349

Notter B., Hurni H., Wiesmann U., Abbaspour K.C., 2012, Modelling water provision as an ecosystem service in a large East African river basin, Hydrology and Earth System Sciences, 16, 69-86, DOI: 10.5194/hess-16-69-2012

Peterson T.C., Golubev V.S., Groisman P.Y., 1995, Evaporation losing its strength, Nature, 377, 687-688, DOI: $10.1038 / 377687 \mathrm{~b} 0$

Priestley C.H.B., Taylor R.J., 1972, On the assessment of surface heat flux and evaporation using large-scale parameters, Monthly Weather Review, 100 (2), 81-92, DOI: 10.1175/1520-0493(1972)100<0081:OTAOSH >2.3.CO;2

Saha S., Moorthi S., Pan H.-L., Wu X., Wang J., Nadiga S., Tripp P., Kistler R., Woollen J., Behringer D., Liu H., Stokes D., Grumbine R., Gayno G., Wang J., Hou Y.-T., Chuang H.-Y., Juang H.-M., Sela J., Iredell M., Treadon R., Kleist D., Van Delst P., Keyser D., Derber J., Ek M., Meng J., Wei H., Yang R., Lord S., van den Dool H., Kumar A., Wang W., Long C., Chelliah M., Xue Y., Huang B., Schemm J.-K., Ebisuzaki W., Lin R., Xie P., Chen M., Zhou S., Higgins W., Zou C.-Z., Liu Q., Chen Y., Han Y., Cucurull L., Reynolds R.W., Rutledge G., Goldberg M., 2010, The NCEP Climate Forecast System Reanalysis, Bulletin of the American Meteorological Society, 1015-1057, DOI: 10.1175/2010BAMS3001.1.

Sharma R.K., Goswami S.B., Tiwari S., Kar S.C., 2015, Evaluation of daily rainfall-runoff simulations in Narmada River basin, International Journal of Earth Sciences and Engineering, 8 (3), 1123-1132

Siebert S., Burke J., Faures J.M., Frenken K., Hoogeveen J., Döll P., Portmann F.T., 2010, Groundwater use for irrigation - a global inventory, Hydrology and Earth System Sciences, 14, 1863-1880, DOI: 10.5194/hess-14-1863-2010

Spruill C.A., Workman S.R., Taraba J.L., 2000, Simulation of daily and monthly stream discharge from small watersheds using the SWAT model, Transactions of the ASAE, 43 (6), 1431-1439, DOI: 10.13031/2013.3041

Stehr A., Debels P., Romero F., Alcayaga H., 2008, Hydrological modelling with SWAT under conditions of limited data availability: evaluation of results from a Chilean case study, Hydrological Sciences Journal, 53 (3), 588-601, DOI: 10.1623/hysj.53.3.588

Vazquez-Amabile G.G., Engel B.A., 2005, Use of SWAT to compute groundwater table depth and stream flow in the Muscatatuck River watershed, Transactions of the ASAE, 48 (3), 991-1003

Wada Y., Van Beek L.P.H., Van Kempen C.M., Reckman J.W.T.M., Vasak S., Bierkens M.F.P., 2010, Global depletion of groundwater resources, Geophysical Research Letters, 37 (20), DOI: 10.1029/2010GL044571

Waliser D., Seo K.-W., Schubert S., Njoku E., 2007, Global water cycle agreement in the climate models assessed in the IPCC AR4, Geophysical Research Letters, 34 (16), DOI: 10.1029/2007GL030675

Wang X., Melesse A.M., Yang W., 2006, Influences of potential evapotranspiration estimation methods on SWAT's hydrologic simulation in a Northwestern Minnesota watershed, Transactions of the American Society of Agricultural and Biological Engineers, 49, 1755-1771, DOI: 10.13031/2013.22297

Xu C.-Y., Singh V.P., 2005, Evaluation of three complementary relationship evapotranspiration models by water balance approach to estimate actual regional evapotranspiration in different climatic regions, Journal of Hydrology, 308 (1-4), 105-121, DOI: 10.1016/j.jhydrol.2004.10.024 
